\title{
A Comparative Study of Intuitive-imitative and Analytic-linguistic Approaches towards Teaching English Vowels to L2 Learners
}

\author{
Mahmood Hashemian \\ English Department, Shahrekord University, Shahrekord, Iran \\ Email:m72h@hotmail.com \\ Batool Fadaei \\ English Department, Shahrekord University, Shahrekord, Iran \\ Email: batoolfadaee147@gmail.com
}

\begin{abstract}
In spite of the importance of pronunciation in L2 learning, its training has remained largely neglected in the field of English language teaching (ELT) and does not have a secure place in most L2 curricula (Setter \& Jenkins, 2005). On the importance of teaching speech features, Celce-Murcia, Brinton, and Goodwin (1996) introduce the intuitive-imitative approach, an approach that deals with listening and imitating the sounds and rhythms of an $\mathrm{L} 2$ without explicit teaching. It can be done by using audiotapes, videos, and computer programs. On the other hand, a majority of $\mathrm{L} 2$ teachers use the analytic-linguistic approach, an approach in which they use explicit and structured teaching of speech features by articulatory descriptions, charts of speech, phonetic alphabet, and vowel charts. This study was an attempt to investigate the effectiveness of intuitive-imitative and analytic-linguistic approaches on teaching pure vowels and diphthongs, and also, sought to examine whether elementary $L 2$ learners respond differently to the abovementioned approaches. The participants were 40 Iranian $\mathrm{L} 2$ learners attending a language school in Isfahan in the form of 2 elementary classes. In one class, English vowels were taught through intuitive-imitative approach, and in the other one, through analytic-linguistic approach. Then, the participants $\square$ audiorecorded data were given to an English native-speaker instructor to be rated. The results of the paired samples $t$ test and comparing means indicated that the L2 learners taught through the intuitive-imitative approach had a better pronunciation in diphthongs, and accordingly, the L2 learners taught through the analytic-linguistic approach outperformed in pure vowels. The study could have some implications for $\mathrm{L} 2$ research and pedagogy that will be discussed throughout the paper.
\end{abstract}

Index Terms —intuitive-imitative approach, analytic-linguistic approach, pure vowels, diphthongs

\section{INTRODUCTION}

While pronunciation and the role it plays are important in getting our meaning across, both transactionally and interactionally, according to Kelly (2000), it is the Cinderella area of L2 teaching. On the definition of pronunciation, Schmitt (2002) defines it as "a term used to capture all aspects of how we employ speech sounds for communication" ( $p$. 219). Moreover, there are some reasons which put emphasis on the importance of pronunciation in learning an L2. On the importance of this neglected area of L2 teaching, Fraser (2006) states that, first, it enhances comprehensibility. Second, when the finite number of sounds, sound clusters, and intonation patterns are mastered, it enables an infinite use. Third, it is of great assistance to those who have integrative motivation, because with native-like pronunciation they will not be marked as foreigners. So, having good pronunciation is important because it is a part of successful communication.

Jones (2002) classifies pronunciation into segmental features (i.e., vowels and consonants) and suprasegmental (prosodic) features like stress, intonation, pitch, and rhythm. Research in different fields of L2 learning and teaching has shown that the use of explicit instruction can have useful effects in learning (Murphy, 2003). According to Fraser and Perth (1999), most L2 teachers now feel that explicit pronunciation teaching is essential.

According to Celce-Murcia, Brinton, and Goodwin (1996), three approaches to pronunciation instruction are generally proposed. These are the intuitive-imitative approach, the analytic-linguistic approach, and the integrative approach. These approaches combine traditional methods and modern techniques.

In the intuitive-imitative approach, as proposed by Celce-Murcia, Brinton, and Goodwin (1996), L2 learners listen and imitate the rhythms and sounds of an L2 without any explicit instruction. Particular technologies are used today for this purpose, such as audiotapes, videos, computer-based programs, and Web sites. On the other hand, in the analytic-linguistic approach, L2 learners are provided with explicit information on pronunciation (e.g., the phonetic alphabet, articulatory descriptions, and vocal charts). 
In a similar vein, Lee (2008) believes that "in integrative approach, pronunciation is viewed as an integral component of communication, rather than an isolated drill" (p. 1). Pronunciation is practiced within meaningful task-based activities. In fact, L2 learners use pronunciation-focused listening activities to facilitate the learning of pronunciation. Also, Lee (2008) claims that there is more focus on the suprasegmentals of stress, rhythm, and intonation as practiced in a discourse beyond the phoneme and word level.

Regarding the integrative approach, Morely (1994) believes that in the aforementioned approach the primary goals of pronunciation teaching are for the L2 learner to develop intelligible speech and be able to communicate in the L2. In this approach, Morely (1991, as cited in Chen, 2007) identifies basic pronunciation goals of functional, intelligibility, functional communicability, increased self-confidence, speech monitoring ability, and speech modification strategies. According to Morely (1994, as cited in Lee, 2008, p. 2), there is a dual-focus oral communication program in which the microlevel instruction is focused on linguistic competence by practice of segmental and suprasegmentals, and the macrolevel pays attention to global elements of communicability, with the goal of developing discourse, sociolinguistic, and strategic competence by using language for communicative purposes.

Derwing and Munro (2005) believe that pronunciation is a multifaceted experience affected by biological, social, and psychological factors which make this skill complex. It is argued that with good pronunciation, a speaker is intelligible despite other errors; with poor pronunciation, a speaker can be very difficult to understand, despite accuracy in other areas (Fraser, 2000).

There are two basic assumptions about the learning of L2 pronunciation. The first, based on the critical period hypothesis $(\mathrm{CPH})$, claims that it is virtually impossible for adults to acquire native-like pronunciation in an L2. The second, arising primarily from the work of Krashen (1982), insists that pronunciation is an acquired skill and focused instruction is useless, so pronunciation cannot be affected by focused practice and the teaching of formal rules. In a similar vein, Jones (2002) argues that factors that mostly affect the learning of L2 phonology (e.g., L1, interaction with native speakers, and motivation) seem to be those on which L2 teachers and classrooms have the least influence.

On the other hand, there are two different perspectives towards pronunciation teaching. According to Harmer (2001), the first perspective assumes that teaching of pronunciation not only makes L2 learners aware of different sounds and sound features but can also improve their speaking immediately. In contrast, the second perspective presupposes a small role for L2 teachers to influence the natural course of phonological development and is rooted in ineffectiveness of pronunciation teaching.

Some reasons may lead to the controversies among L2 teachers in teaching pronunciation. Fraser (2002) believes that this uncertainty about the way of teaching may arise from the selection of pronunciation features, the ordering of the features selected, the type(s) of the discourse to practice pronunciation, undesirability of L2 learners, and lack of enough time. Several empirical studies (e.g., Bruck \& Genessee, 1995; Catford \& Pisoni, 1970; Cicero \& Royer, 1995; Couper, 2006; MuraKawa, 1981; Neufeld, 1987; Verhoeven, 1994) have shown positive effects for explicit teaching of different aspects of pronunciation like segments, suprasegmentals, and fluency.

The learning of English pronunciation has been the subject of investigation for a long time. Celce-Murcia, Brinton, and Goodwin (1996) have illustrated several pronunciation teaching approaches ever since L2 teaching started. The approaches are presented in Table 1:

TABLE 1.

PRONUNCIATION TEACHING APPROACHES

\begin{tabular}{|c|c|c|c|}
\hline Years & \multicolumn{2}{|l|}{ Approach } & Definition \\
\hline $\begin{array}{l}\text { late } 1800 \text { s \& late } \\
1900 \text { s }\end{array}$ & \multicolumn{2}{|c|}{ Direct Method } & $\begin{array}{l}\text { Teachers provided L2 learners with a model for native-like speech. By } \\
\text { listening and then imitating the modeler, L2 learners improved their } \\
\text { pronunciation. }\end{array}$ \\
\hline 1940s-1950s & \multicolumn{2}{|c|}{$\begin{array}{l}\text { Audio-Lingual Method in the US } \\
\& \text { Oral Approach in the UK }\end{array}$} & $\begin{array}{l}\text { Pronunciation was taught explicitly from start, and L2 learners imitated } \\
\text { or repeated after their teacher or a recording model. }\end{array}$ \\
\hline $1960 \mathrm{~s}$ & \multicolumn{2}{|c|}{ Cognitive Approach } & This de-emphasized pronunciation in favor of grammar and vocabulary \\
\hline \multirow[t]{2}{*}{ 1970s } & \multicolumn{2}{|l|}{ Silent Way } & $\begin{array}{l}\text { L2 learners focused on the sound system without having to learn a } \\
\text { phonetic alphabet. Attention was on the accuracy of sounds and } \\
\text { structures of the L2 from the outset. }\end{array}$ \\
\hline & \multicolumn{2}{|c|}{ Community Language Learning } & $\begin{array}{l}\text { The pronunciation syllabus was primarily student-initiated and designed. } \\
\text { The approach was imitative. }\end{array}$ \\
\hline $\begin{array}{l}\text { Mid-late 1970s } \\
\text { (1980s-today) }\end{array}$ & \multicolumn{2}{|c|}{ Communicative Approach } & $\begin{array}{l}\text { The ultimate goal was communication. Teaching pronunciation was } \\
\text { urgent and it was necessary in oral communication. Techniques to teach } \\
\text { pronunciation were listening and imitating, phonetic training, minimal } \\
\text { pair drill, and so on. }\end{array}$ \\
\hline \multirow{3}{*}{$20^{\text {th }}$ century } & \multicolumn{2}{|c|}{$\begin{array}{l}\text { Grammar Translation \& } \\
\text { Reading-Based Approaches }\end{array}$} & $\begin{array}{l}\text { Oral communication was not the primary goal of L2 instruction. } \\
\text { Therefore, little attention was given to speaking and almost none to } \\
\text { pronunciation. }\end{array}$ \\
\hline & \multirow{2}{*}{$\begin{array}{l}\text { Naturalistic } \\
\text { Methods }\end{array}$} & $\begin{array}{l}\text { Total Physical } \\
\text { Response }\end{array}$ & $\begin{array}{l}\text { L2 learners began to speak when they were ready. L2 teachers were } \\
\text { tolerant of L2 learners' errors. }\end{array}$ \\
\hline & & $\begin{array}{l}\text { Natural } \\
\text { Approach }\end{array}$ & $\begin{array}{l}\text { The initial focus on listening without pressure to speak gave L2 learners } \\
\text { opportunity to internalize sounds. }\end{array}$ \\
\hline Today & \multicolumn{2}{|c|}{ New Directions } & $\begin{array}{l}\text { The use of fluency-building activities, accuracy-oriented exercises, and } \\
\text { adaptation of authentic materials is dominant. }\end{array}$ \\
\hline
\end{tabular}


In an attempt to define teaching pronunciation, Lee $(2008$, p. 7) defines it as part of the communicative approach and traditionally L2 teachers of pronunciation had used the phonetic alphabet and activities like transcription practice, diagnostic passages, recognition or discrimination tasks, and developmental approximation drills. Also, other popular methods were listening, imitating, visual aids, practice of vowel shifts related by affixation, and recordings of L2 learners' production. Some L2 learners benefited from these methods, but others did not learn the pronunciations of other languages.

Although the number of studies which have focused on teaching suprasegmental features of an L2 is at large (e.g., Champagne-Muzar, Scheneideran, \& Bourdages, 1993; Derwing, Munro, \& Wiebe, 1998; Hall, 1997), there are few number of studies, to the best of the present researchers' knowledge, which have focused on the segmental features (i.e., vowels and consonant) of an L2. Champagne-Muzar, Scheneideran and Bourdages (1993) implemented a program focusing on both French segmentals and suprasegmentals that consisted of 12 one-hour lessons. The result of the posttests indicated that the experimental group surpassed the control group, showing that instruction was beneficial in both discrimination and production of pronunciation features. Derwing, Munro and Wiebe (1998) provided empirical evidence for the importance of teaching suprasegmentals in a study that compared three groups of L2 learners over 12 weeks and concluded that the L2 learners responded very positively to the tests after the materials were taught.

By an advanced understanding of an L2, specialists (e.g., Jenkins, 2002) agree that explicit instruction in pronunciation is essential in an L2 curriculum. With the dominance of communicative language teaching (CLT), as Pennington and Richards (1986) have pointed out, teaching of pronunciation shifts from a phonological accuracy to a global conversational competence and is thought to be taught as an integral part of oral communication.

In fact, new directions in teaching and learning L2 pronunciation, as Celce-Murcia, Brinton, and Goodwin (1996) argue, have come from other fields (e.g., drama and psychology). The techniques they have highlighted are the use of fluency-building activities as well as accuracy-oriented exercises, adaptation of authentic materials, and the use of instructional technology in pronunciation teaching. In line with their work, Lee (2008) also believes that the current technology equipment used in education includes computers, digital cameras, scanners, LCD panels, and projectors. Based on the aforementioned approaches, this study aims to investigate the effectiveness of intuitive-imitative and analytic-linguistic approaches in teaching pure vowels and diphthongs, and to examine whether these approaches play any role in vowels teaching to L2 learners. Accordingly, the following null hypotheses are formulated:

- $\mathrm{H}_{01}$ : There is no relationship between elementary L2 learners' performance on pronouncing vowels (pure vowels and diphthongs) and the intuitive-imitative approach to teaching pronunciation.

- $\mathrm{H}_{02}$ : There is no relationship between elementary L2 learners' performance on pronouncing vowels (pure vowels and diphthongs) and the analytic-linguistic approach to teaching pronunciation.

\section{METHODOLOGY}

\section{A. Participants}

The participants were 40 Iranian L2 learners attending a language school in Isfahan in the form of two classes, each with 20 learners. The participants were enrolled at the elementary level, using a placement test administered to them by the language school. All the participants were female whose age ranged from 13 to 18. They attended an ELT course in the summer, and received approximately 8 hours a week of L 2 instruction. For their term, they were supposed to study Interchange Intro written by Jack C. Richard (2005). Table 2 summarizes the characteristics of the participants:

TABLE 2 .

CHARACTERISTICS OF THE PARTICIPANTS

\begin{tabular}{|l|l|ll|}
\hline & Intuitive-Imitative Approach & Analytic-Linguistic Approach \\
\hline Average Age & 14 & 15.5 & 20 \\
\hline Gender \& Number & Female & Female & \\
\hline Place of English Learning & Class A & Class B & \\
\hline
\end{tabular}

\section{B. Materials}

The basic material was based upon the book How to Teach Pronunciation written by Kelly (2000). The present researchers used the audio CD of the book for chapter 3, under the title of Vowels. It was used in Class A where vowels were to be taught through the intuitive-imitative approach.

Also, vocal charts were used in this study that show characteristics of each vowel, its position inside the mouth, and position of the lips.

\section{Procedure}

In this study, there were two elementary classes with 20 learners in each. They took part in classes 6 days a week in the afternoon, and their term consisted of 20 sessions, each 80 minutes. In each session, 15 minutes of class time was allocated to teaching English vowels. In one class, English vowels were taught through the intuitive-imitative approach, and in the other through the analytic-linguistic approach. 
In Class A, English vowels were taught through the intuitive-imitative approach. This approach assumes that L2 learners' ability to listen to and imitate the rhythms and sounds of the L2 will lead to the development of an acceptable pronunciation without the intervention of any explicit information. As it was mentioned above, to teach through this approach, the audio CD of the book How to Teach Pronunciation written by Kelly (2000) was used. The participants listened to this $\mathrm{CD}$ in each session for about 15 minutes, and each time the focus was on one or two vowels. The participants listened carefully and tried to imitate the vowels and their related words. They are usually grouped in the following way:

1. Centering diphthongs: End with a glide toward /ə/. They are called centering because /ə/ is a central vowel (e.g., clearing // ə/, sure /uə/, there /eə/).

2. Closing diphthongs: End with a glide toward / / or toward /u/ (e.g., they /eı /, boy /o । /, mighty /aı /, go /əu/, now /au/).

It is worth mentioning that in this language school, features (i.e., segmental and suprasegmental) of pronunciation were not taught due to time constraints, and the main goal was making the participants able to communicate. In other words, fluency was considered more important than pronunciation accuracy, and this fact ensured the present researchers that the participants had not had instruction in this respect before. These vowels and related words are shown in Table 3:

TABLE 3.

ENGLISH VOWELS AND WORDS

\begin{tabular}{|l|l|}
\hline Vowels & Examples \\
\hline i: & bead, key, cheese, scene, police, people \\
\hline I & hit, sausage, biggest, rhythm, busy, women \\
\hline u & book, good, woman, push, pull \\
\hline u: & food, rude, true, who, fruit, soup \\
\hline e & egg, left, said, head, read, instead, any \\
\hline ə & about, paper, banana, nation, the \\
\hline 3: & shirt, her, further, pearl, serve \\
\hline o: & fork, snore, taught, bought, board, pour, all, law, horse \\
\hline$æ$ & hat, attack, antique \\
\hline$\Lambda$ & run, uncle, front, does, come, flood \\
\hline a: & far, part, half, class, command, clerk, aunty \\
\hline I $ə$ & beer, beard, fear, pierce, here, idea \\
\hline uə & sure, tour, obscure \\
\hline eə & where, wear, chair, dare, stare, there \\
\hline el & cake, way, weight, say, pain, they, vein \\
\hline o I & toy, avoid, voice, enjoy, boy \\
\hline al & high, tie, buy, kite, might, cry, eye \\
\hline əu & go, snow, toast, home, hello, although \\
\hline au & house, loud, down, how \\
\hline
\end{tabular}

In Class B, English vowels were taught through the analytic-linguistic approach. This approach recognizes the importance of an explicit intervention of pronunciation pedagogy in L2 learning. The participants were provided with explicit information on pronunciation (e.g., the phonetic alphabet, articulatory descriptions, and vocal charts). In order to teach according to this approach, the characteristics of each vowel were explained by showing the positions of the lips, articulatory descriptions, and the vocal charts as Kelly (2000) has explained in the aforementioned book. In the analytic-linguistic approach, the researchers taught about the position of the lips and its division in three categories:

1. Rounded: The lips are pushed forward into the shape of a circle (e.g., /u/).

2. Spread: The corners of the lips move away from each other, as when smiling (e.g., /i:/).

3. Unrounded: The lips are not noticeably rounded or spread (e.g., /ə/).

Also, the researchers explained about close, mid, and open vowels through the analytic-linguistic approach:

1. For close vowels, the tongue is quite high in the mouth.

2. For mid vowels, the tongue is neither high nor low in the mouth.

3. For open vowels, the tongue is low in the mouth.

It should be mentioned that because the participants were elementary L2 learners, all the above explanations were in Persian language and also, the participants' voices were recorded at the end of the term when they were practicing one by one and pronounced the vowels. Then, through their recorded voice, the data analysis was done. The vowels are shown in Table 4: 
TABLE 4.

ENGLISH VOWELS AND THEIR CHARACTERISTICS

\begin{tabular}{|c|c|}
\hline Vowels & Characteristics \\
\hline i: & $\begin{array}{l}\text { The front of the tongue is slightly behind and below the closed front position. The lips are spread. The tongue is } \\
\text { tense, and the sides of the tongue touch the upper molars. }\end{array}$ \\
\hline I & $\begin{array}{l}\text { The part of the tongue slightly nearer the center is raised to just above the half-close position. The lips are spread } \\
\text { loosely, and the tongue is more relaxed. The sides of the tongue may touch the upper molars. }\end{array}$ \\
\hline $\mathrm{u}$ & $\begin{array}{l}\text { The part of the tongue behind the center is raised above the half-close position. The lips are rounded, but loosely } \\
\text { so. The tongue is relatively relaxed. }\end{array}$ \\
\hline $\mathrm{u}:$ & The back of the tongue is raised below the close position. The lips are rounded. The tongue is tense. \\
\hline e & $\begin{array}{l}\text { The front of the tongue is between the half-open and half-close positions. The lips are loosely spread. The sides } \\
\text { of the tongue may touch the upper molars. }\end{array}$ \\
\hline$\partial$ & $\begin{array}{l}\text { The center of the tongue is between the half-close and half-open positions. The lips are relaxed and naturally } \\
\text { spread. }\end{array}$ \\
\hline 3: & $\begin{array}{l}\text { The center of the tongue is between the half-close and half-open positions. The lips are relaxed and neutrally } \\
\text { spread. }\end{array}$ \\
\hline 0: & The back of the tongue is raised to between the half-open and half-close positions. The lips are loosely rounded. \\
\hline$æ$ & The front of the tongue is raised below the half-open positions. The lips are neutrally open. \\
\hline$\Lambda$ & The center of the tongue is raised to above the fully open position. The lips are neutrally open. \\
\hline a: & The tongue, between the center and the back, is in the fully open position. The lips are neutrally open. \\
\hline 12 & The lips are neutral, but with a small movement from spread to open. \\
\hline uə & The lips are loosely rounded, becoming neutrally spread. \\
\hline eə & The lips remain neutrally open. \\
\hline el & The lips are spread. \\
\hline 01 & The lips start open and rounded and change to neutral. \\
\hline al & The lips move from neutral to loosely spread. \\
\hline$\partial \mathrm{\partial u}$ & The lips are neutral but change to loosely rounded. \\
\hline $\mathrm{au}$ & $\begin{array}{l}\text { The lips start neutral, with a movement to loosely round. The glide is not always completed, as the movement } \\
\text { involved is extensive. }\end{array}$ \\
\hline
\end{tabular}

At the end of the term, the participants were asked to pronounce pure vowels and diphthongs presented in words again. For each student in Class A and Class B, five words which had pure vowels and five words which had diphthongs were selected, respectively. Their voices were audio-recorded as they participated one by one.

\section{RESULTS AND DISCUSSION}

The data were subjected to analysis to explore the probable effect of the two teaching approaches on the participants' performance in pronouncing the English vowels. A female native English-speaker rated (or judged) the recorded data. The native speaker was completely informed of the aim of the study. She awarded one point to every word pronounced with correct pronunciation regarding pure vowels and diphthongs, and zero (no point) to those with wrong pronunciation, respectively. One important point is that, in scoring, any wrong stress on individual words was ignored - the main point was just correct pronunciation of pure vowels and diphthongs. After rating the participants' performance, the researchers, using the Statistical Package for Social Science (SPSS), ran paired samples $t$ test and compared the means in each group to analyze the data.

In order to test the first null hypothesis, the researchers run a paired samples $t$ test between the scores of the pure vowels and diphthongs in Class A where pronunciation teaching was based on the intuitive-imitative approach. Table 5 represents the inferential statistics of the data:

TABLE 5 .

PAIRED SAMPLES $T$ TEST

\begin{tabular}{|c|c|c|c|c|c|c|}
\hline & \multicolumn{3}{|c|}{ Paired Differences } & \multirow{3}{*}{$t$} & \multirow{3}{*}{$d f$} & \multirow{3}{*}{$\begin{array}{l}\text { Sig. } \\
(2 \text {-tiled })\end{array}$} \\
\hline & \multirow[t]{2}{*}{ Mean } & \multicolumn{2}{|c|}{$\begin{array}{l}\text { 95\% Confidence Interval of the } \\
\text { Differences }\end{array}$} & & & \\
\hline & & Lower & Upper & & & \\
\hline $\begin{array}{l}\text { Pair } 1 \\
\text { Intuitive-Imitative: Pure Vowels } \\
\text { Intuitive-Imitative: Diphthongs }\end{array}$ & .45000 & .19934 & .70066 & 3.758 & 19 & 0.001 \\
\hline
\end{tabular}

*Sig. $p<0.05$

The probability value of the test is 0.001 which is less than 0.05 . So, it was concluded that there was a significant difference between the two scores of the pure vowels and diphthongs pronunciation; therefore, the first null hypothesis is rejected. Because there was a significant difference between the two groups, the next step was to find out which set of scores (i.e., pure vowels diphthongs) was higher. To do so, Table 6 shows a comparison of the two groups $\square$ mean scores: 
TABLE 6.

DESCRIPTIVE STATISTICS

\begin{tabular}{|l|c|c|c|}
\hline & $\boldsymbol{N}$ & Mean & Std. Deviation \\
\hline Intuitive-Imitative: Pure Vowels & 20 & 4.000 & .36274 \\
\hline Intuitive-Imitative: Diphthongs & 20 & 4.4500 & .39403 \\
\hline
\end{tabular}

As the mean score of the two groups show, the mean score for the diphthongs was higher than that of the pure vowels. Therefore, in teaching the diphthongs, which are combinations of vowel sounds, the intuitive-imitative approach paid off better.

In order to test the second null hypothesis, the researchers ran a paired samples $t$ test between the scores of the pure vowels and diphthongs in Class B where pronunciation teaching was based on the analytic-linguistic approach. Table 7 shows the inferential statistics of the data:

TABLE 7.

PAIRED SAMPLES T TEST

\begin{tabular}{|c|c|c|c|c|c|c|}
\hline & \multicolumn{3}{|c|}{ Paired Differences } & \multirow{3}{*}{$t$} & \multirow{3}{*}{$d f$} & \multirow{3}{*}{$\begin{array}{l}\text { Sig. } \\
(2 \text {-tiled) }\end{array}$} \\
\hline & \multirow[t]{2}{*}{ Mean } & \multicolumn{2}{|c|}{$\begin{array}{l}\text { 95\% Confidence Interval of the } \\
\text { Differences }\end{array}$} & & & \\
\hline & & Lower & Upper & & & \\
\hline $\begin{array}{l}\text { Pair } 2 \\
\text { Intuitive-Imitative: Pure Vowels } \\
\text { Intuitive-Imitative: Diphthongs }\end{array}$ & -.72500 & -1.02366 & -.42634 & -5.081 & 19 & 0.000 \\
\hline
\end{tabular}

The probability value of the test is 0.000 which is less than 0.05 . So, it was concluded that there was a significant difference between the two scores of the pure vowels and diphthongs pronunciation; therefore, the second null hypothesis is rejected. Because there was a significant difference between the two groups, the next step was to find out which set of scores (i.e., pure vowels diphthongs) was higher. To do so, Table 8 shows a comparison of the two groups $\square$ mean scores:

TABLE 8.

DESCRIPTIVE STATISTICS

\begin{tabular}{|l|l|l|l|}
\hline \multicolumn{1}{|c|}{ DESCRIPTIVE STATISTICS } \\
\hline Intuitive-Imitative: Pure Vowels & $\boldsymbol{N}$ & Mean & Std. Deviation \\
\hline Intuitive-Imitative: Diphthongs & 20 & 4.5500 & .45595 \\
\hline
\end{tabular}

As the mean scores of the two groups show, the mean score for the pure vowels was higher than that of the diphthongs. Therefore, in teaching the pure vowels, the analytic-linguistic approach was more effective. The results shows that in pronouncing the pure vowels (e.g., /æ/, /ə/, /u/, /e/, /i:/), the participants performed better via the analytic-linguistic approach after the researchers explained how the tongue changed its position in the mouth.

\section{CONCLUSION}

The results indicate that there is a significant difference between the participants $\square$ performances after the instruction. In fact, participants improved in performance after making them aware of the pure vowels pronunciation by the phonetic alphabet, articulatory descriptions, and vocal charts. At the end of the term, the participants had better pronunciation in close pure vowels (e.g., /i:/, // /, /u/, /u:/), mid pure vowels (e.g., /ə/, /e/, /3:/, /e/), and open pure vowels (e.g., /æ/, / / /, /a:/). So, in pronunciation of pure vowels, the analytic-linguistic approach is more effective. Thus awareness or consciousness-raising can be influential in acquiring pure vowels pronunciation. Furthermore, implicit teaching of diphthongs through listening to their pronunciation and trying to imitate them can give beneficial results in order to teach diphthongs to learners. Most participants who could not correctly produce the vowels (pure and diphthongs) apparently improved their performance after having been taught about the approaches. So, according to findings of this study, there are 2 ways to teach vowel sounds:

1. Using a phonemic chart: The chart gives the information that L2 learners need in order to be able to use it independently, especially for teaching pure vowels through the analytic-linguistic approach.

2. Repetition and imitation of sounds, especially for diphthongs and teaching through the intuitive-imitative approach.

The analytic-linguistic approach adopts a more analytic view in presenting different linguistic features involved in pronunciation. As Celce-Murcia, Brinton, and Goodwin (1996) state, this approach uses information and tools such as a phonetic alphabet, articulatory descriptions, charts of vocal apparatus, contrastive information, and other aids to supplement listening, imitation, and production. It explicitly informs L2 learners and focuses attention on the sounds and rhythms of the L2.

The purpose of dealing with a sound in isolation in the classroom helps L2 learners move toward more successful pronunciation which has an effect on communication and intelligibility. In spoken language, all sounds are, of course, important, but at times certain sounds seem central to the success of communication. In fact, poor pronunciation can 
affect intelligibility and vowels present L2 learners with particular difficulty. Every time someone speaks in class, pronunciation is a matter for consideration.

So, the results of this study are, in part, in line with what Jenkins (2002) claims to be important to teach pronunciation. By an advanced understanding of an L2, Jenkins (2002) agrees that explicit instruction in pronunciation is essential in an L2 curriculum, as it is found in this study that the analytic-linguistic approach works better toward teaching pure vowels. But concerning teaching of diphthongs, the results run contrary to what Jenkins (2002) has claimed. In other words, the explicit instruction does not work to teach diphthongs, and the intuitive-imitative approach is more helpful. To conclude, with the dominance of CLT, as Pennington and Richards (1986) have pointed out, pronunciation teaching shifts from a phonological accuracy to a global conversational competence and is thought to be taught as an integral part of oral communication.

Moreover, this study is against what the $\mathrm{CPH}$ claims, according to which it is virtually impossible for adults to acquire native-like pronunciation in an L2, and based on which explicit teaching of pronunciation is useless. It is, thus, argued that although the participants had passed the "critical" period, they still managed to achieve high proficiency in producing vowels through the intuitive-imitative and the analytic-linguistic approaches.

To conclude, it would suffice to mention what Fromkin, Rodman, and Hyams (2003) state:

The knowledge of a language includes knowledge of morphemes, words, phrase, and sentences. It also includes the sounds of language and how they may be put together to form meaningful units. Although there may be some sounds in one language that are not in another, the sounds of all the languages of the world together constitute a limited set of the sounds that the human vocal tract can produce. (p. 231)

Thus, the findings of this study may help both L2 teachers and learners to have their own fair share from the implications of this study, and the outcomes may pave the way for better teaching of vowels to L2 learners. It is hoped that the results of the study could shed some light on the process involved between the teaching approach and L2 learners $\square$ performance on pronouncing vowels.

\section{REFERENCES}

[1] Brab, C. (2005). Suprasegmantals and comprehensibility: A comparative study in accent modification. Ph.D. dissertation, Wichita State University.

[2] Bruck, M. \& Genesee, G. (1995). Phonological awareness in young second language learners. Journal of Child Language 22, 307-324.

[3] Catford, J. \& Pisoni, D. (1970). Auditory vs. articulatory training in exotic sounds. Modern Language Journal 54, $477-481$.

[4] Champagne-Muzar, C., Schneiderman, E. I. \& Bourdages, J. S. (1993). Second language accent: The role of the pedagogical environment. International Review of Applied Linguistics 31, 143-160.

[5] Chen, C. F. (2007). Computer assisted language learning and teaching. http://www.nkfust.edu.tw/nemchen/CALL/ (accessed 20/4/2007).

[6] Cicero, C. \& Royer, J. (1995). The development and cross-language transfer of phonological awareness. Contemporary Educational Psychology 20, 275-303.

[7] Celce-Murcia, M., Brinton, D. M. \& Goodwin, J. M. (1996). Teaching pronunciation. Cambridge: Cambridge University Press.

[8] Couper, G. (2006). The short and long-term effects of pronunciation instruction. Prospect 21, 46-66.

[9] Derwing, T. M. \& Munro, M. J. (2005). Second language accent and pronunciation teaching: a research-based approach. TESOL Quarterly 39.3, 379-397.

[10] Derwing, T., Munro, M. J. \& Wiebe, G. (1998). Pronunciation instruction for "fossilized" learners: Can it help? Applied Language Learning 8, 217-235.

[11] Fraser, H. (2000). Coordinating improvements in pronunciation teaching for adult learners of English as a second language. Presented at the ANTA Innovative Project. Canberra: DETYA.

[12] Fraser, H. (2002). Change, challenge, and opportunity in pronunciation and oral communication. http://www-personal.une.edu.au/ hfraser/docs (accessed 20/7/2010).

[13] Fraser, H. (2006). Helping teachers help students with pronunciation: A cognitive approach. Prospect: An Australian Journal of TESOL. http://www.ameprc.mq.edu.au/docs/prospect_journal/volum_21_no_1/21_1_5_Fraser.pdf (accessed 3/3/2008).

[14] Fraser, H. \& Perth, H. F. (1999). ESL pronunciation teaching: Could it be more effective? Presented at the ALAA conference. Akmidale: University of New England.

[15] Fromkin, V., Rodman, R. \& Hyams, N. (2003). An introduction to language (7th edn.). U.S.: Thomson, Heinle.

[16] Hall, S. (1997). Integrating pronunciation for fluency in presentation skills. www.personal.une.edu.au/hfraser/docs/ (accessed 20/7/2010).

[17] Harmer, J. (2001). The practice of English language teaching (3rd edn.). China: Pearson Education Limited.

[18] Jenkins, J. (2002). A social-linguistically based, empirically researched pronunciation syllabus for English as an international language. Applied Linguistics 23.1, 83-103.

[19] Jones, R. H. (2002). Beyond 'listen and repeat': Pronunciation teaching materials and theories of second language acquisition. In J. Richards \& W. A. Renandya (eds.), Methodology in language teaching: An anthology of current practice. Cambridge: CUP, 178-187.

[20] Kelly, G. (1969). 25 centuries of language teaching. Rowley, MA: Newbury House.

[21] Kelly, G. (2000). How to teach pronunciation. Malaysia: Pearson Education Limited.

[22] Krashen, S. (1982). Principles and practice in second language acquisition. New York: Pergamon.

[23] Lee, S. T. (2008). Teaching pronunciation of English using computer assisted learning software: An active research study in an institute of technology in Taiwan. M.A. thesis, Australian Catholic University. 
[24] Morely, J. (1991). The pronunciation component in teaching English to speakers of other languages. TESOL Quarterly 25.1, $51-74$.

[25] Morely, J. (1994). A multidimensional curriculum for speech-pronunciation instruction. In J. Morely (ed.), Pronunciation pedagogy and theory: New views, new directions. Virginia: TESOL Inc., 66-91.

[26] Murakawa, H. (1981). Teaching English pronunciation to Japanese adults. Ph.D. dissertation, University of Texas, Austin.

[27] Murphy, J. (2003). Pronunciation. In D. Nunan (ed.), Practical English language teaching. Boston: McGraw-Hill, 111-128.

[28] Neufeld, G. G. (1987). On the acquisition of prosodic and articulatory features in adult Language learning. In G. Ioup \& S. Weinberger (eds.), Interlanguage phonology: The acquisition of a second language sound system. Cambridge, MA: Newbury House Publishers, 321-332.

[29] Pennington, M. \& Richards, J. (1986). Pronunciation revisited. TESOL Quarterly 20.2, 207-226.

[30] Richards, J. C. (2005). Intro (3rd edn.). Cambridge: CUP.

[31] Schmitt, N. (2002). An introduction to applied linguistics. London: Oxford University Press.

[32] Setter, J. \& Jenkins, J. (2005). Pronunciation. Language Teaching 38.1, 1-17.

[33] Verhoeven, L. (1994). Transfer in bilingual development: The linguistic interdependence hypothesis revisited. Language Learning 44, 381-384.

Mahmood Hashemian is an assistant professor at Shahrekord University. His area of research includes cognitive-semantic linguistics, sociolinguistics, and applied linguistics. He has published articles in academic journals such as IJAL, IJLS, JALS, Linguistik-Online, JLTR, TPLS, Iranian EFL Journal, and International Journal of Social Sciences. Also, he has given lectures in conferences such as TELLSI (4, 7, \& 8), LDP2010, and ELT in the Islamic World.

Batool Fadaei got her B.A. in English Translation from Shahrekord University and is now an M.A. TEFL student at the same university. Her areas of interest include psycholinguistics, sociolinguistics, and cognitive linguistics. And, she has been teaching English at various language institutes for more than three years. 